\title{
Causes and Effects of Delay on African Construction Projects: A State of the Art Review
}

\author{
Abebe Demisew Gashahun \\ Lecturer, Construction Technology and Management Academic Program, Institute of Technology, Debre \\ Markos University, Debre Markos 251, Ethiopia) P.O. Box: 269
}

\begin{abstract}
The time for the performance of a construction project is usually the soul to the stack of the construction industry. Construction delay is one of the basic constraints to accomplish the project objectives in Africa. This study aims to find the causes and effects of construction delays in African. A thorough literature review has been done following the content analysis method. The relevant literature of 17 African countries was collected from the scholarly journals published from 2010 to 2020. In total 65 potential causes of delay under 10 major groups are identified. Frequency and ranking of these factors have been done. The factors, change/variations order by the client, contractors' infective project planning and scheduling, consultants' delay in approving the major change, design team's insufficient site investigation, resources shortage and price fluctuation, poor communication among parties and unfavorable weather conditions are recognized as critical causes of delay in Africa. On the other hand, time and cost overrun and poor quality of construction is the major effect of delays. Selecting competent consultants, design teams, contractors, and suppliers, involving stakeholders at the planning stage of the project, efficient communication, and adapting appropriate legislation are the corresponding mitigation mechanisms of delay for Africa construction projects.
\end{abstract}

Keywords: Africa, Causes, Construction, Delays, Effects, Mitigations

DOI: $10.7176 / \mathrm{CER} / 12-5-04$

Publication date:May $31^{\text {st }} 2020$

\subsection{Introduction}

Construction projects are complex human endeavors that entail extensive planning and tight control if they are to be successful. In any industry and any country of the Globe, they have always posed difficult challenges to the project teams and project stakeholders, challenges such as delays in project delivery, costs overrun, quality control, and profitability. Besides, Construction, by its very nature, is a risky business. Forecasting its duration is part of what makes it risky. Contractors estimating projects without a complete understanding of the time components, that unnecessarily increasing their risk and exposure to delays.

Most of the projects delivered in recent years in Africa have failed under the conventional project success criteria of being delivered on time, on budget, to the standard and quality required. These results in a huge impact on the continent's already constrained resource as it means loss of extra resources to initially implement the projects, the necessity to maintain infrastructure before their due period, etc. Various reasons can be sited for these. But the most prominent reason has to be the industry's inability to embrace professionalism. As things stand, projects are incepted, planned, and executed outside the realms of professional project management principles and practices. This is bound to result in inefficiencies and ineffectiveness.

The face of the African construction industry is changing. Construction projects on the continent are getting bigger and more complex. According to recent reports, this is owing to rapid urbanization, strong economic growth, a rising middle class, and regional integration in all of Africa's nations. One of the most common concerns of industry experts cited is the escalating cost and delay of projects. This leads firms will likely struggle to maintain their margins in the coming year. When we saw Africa's construction activities in both the numbers and total value of construction projects in regional ways East Africa leads the continent and Southern Africa, North Africa, West Africa, and Central Africa holds from $2^{\text {nd }}$ to $5^{\text {th }}$ ranks respectively (Edinger, 2019).

The construction sector is a key element of national economies and provides critical support for social and economic development and it's a very important service sector with extensive backward and forward linkages in every economy (Alagidede et al., 2016; UN.ECA, 2016). Currently, Africa's construction industry is going through a boom. The construction industry has high contributed to the gross domestic product (GDP) of the nations. According to (Ford et al., 2020) it contributed about $7 \%$ of Kenyan, $11.9 \%$ of Nigerian, 21.5\% average of subSaharan Africa, 32.8\% of Ethiopian, the continental leader, of their GDP over the last decade. Overall Africa is now investing in its infrastructure on average \$108 billion per year (Bank, 2018). construction play a dual role in the economy which are as part of aggregate demand, determining output movements in the short run, and, by augmenting a nation's stock of productive assets, construction activities are central to the determination of longrun economic growth (Alagidede et al., 2016). There is a changing development pattern of the construction industry based on the stage of development of a country's economy (Lopes, 2010).

Ofori (2000) discussed that the construction industry everywhere faces problems and challenges. However, 
in the developing countries, these difficulties and challenges are present alongside a general situation of socioeconomic stress, chronic resource shortages, institutional weaknesses and a general inability to deal with the key issues. There is also evidence that the problems have become greater in extent and severity in recent years. That is why China's involvement in Africa's construction and infrastructure sectors increased. Chinese state-owned and private companies are making strategic inroads into the construction and infrastructure sectors in many African economies at the expense of European and South African companies (Burke et al., 2006).

The construction industry involves a large number of projects participants like contractors, clients, consultants, suppliers, regulatory bodies, financers, publics, etc. It has been observed that risks and uncertainties involve in construction projects are not being addressed and managed efficiently. Therefore, to improve the performance of the construction industry, there is dire need to deal with these risks and uncertainty in an integrated manner to achieve the success of a project in terms of time, cost, and quality. Infrastructure investments in Africa have been growing rapidly. Africa has become one of the leading outsourcing hubs in the world. This sector is considered to be an important key driver of the economic growth of the nations and occupies a pivotal position in the continental development plans. It is seen that economic growth is not being achieved at the desired level due to delays. It has been observed that not much attention is being paid to handle the problem of time overrun by the stakeholders of the construction industry in the continent. Therefore, it is an urgent need to identify actual causes of time delays/overruns so that the delay in time can be minimized. With this background in view, the proposed work is undertaken.

The objective of this paper is to review the past studies related to construction delay factors, their effects, and related mitigation mechanisms of the African construction industry. The specific objectives of the present study are:

$\checkmark \quad$ To identify the common causes of delay in African construction projects

$\checkmark \quad$ To classified and analyzed delays in African construction projects

$\checkmark \quad$ To identify the effects of delays in African construction projects

$\checkmark$ To recommend applicable delay mitigation techniques from the past studies in African scenario.

\subsection{Methodology}

To achieve the objectives, a systematic literature review has been done considering the research papers on potential and critical causes of delays, their frequency, and ranking, effects of delay, the recommendation for reducing construction delay, published from 2010 to 2020 from various sources (Journals, Proceedings, Reports, Books, Web, etc.). This study reviews critic on the construction delay of 17 African countries. Thus, the findings of this study will provide significant knowledge regarding construction delays, their effects, and related mitigation mechanisms in Africa. However, few papers published before 2010 were also considered for some countries where there was no research paper published in 2010 and onward. During the literature search, some keywords like construction delay, time overrun, delay in project delivery, the effect of delays, mitigation techniques of delays, African countries, and the name of an individual African country were used. The stepwise processes for retrieving relevant papers, selecting the contents of the discussion, and critical analysis of the previous findings were discussed.

The potential and critical causes of construction delays were listed, and the frequency among the selected countries and the ranks of the factors in regards to countries were made as shown in Table 1 . The critical causes of delays and their frequencies among 24 selected studies in 17 countries of Africa were shown in Table 2 and briefly discussed. This study also identified the effects of construction delays and accumulated the actions recommended for reducing the construction delays from previous literature. Lesson learned from this study, the conclusion, and future direction of research were drawn at the end.

Thus, as shown in table 1, it is clear that the construction projects in most of the countries have a serious problem regarding managerial, design, and financial issues. From the literature review, this study identified 65 frequent causes of delay and grouped them into ten major categories and listed in Table 2. The following section discusses brief details about the potential factors of delay in 16 African countries and shows their frequency and ranking based on the findings of 21 published studies. 
Table 1: Detail briefing of the selected papers on delays in the African construction industry

\begin{tabular}{|c|c|c|c|c|c|}
\hline No & Research area & $\begin{array}{l}\text { Causes of construction delay (top } 3 \text { causes } \\
\text { within total causes of delay considered in } \\
\text { the particular study) }\end{array}$ & Country & $\begin{array}{l}\text { Publicatio } \\
\text { n Year }\end{array}$ & References \\
\hline 1 & $\begin{array}{l}\text { Causes of } \\
\text { construction time } \\
\text { overruns }\end{array}$ & $\begin{array}{c}\text { Design-related factors } \\
\text { Late decision-making } \\
\text { Shortages of resources }(11) \\
\end{array}$ & $\begin{array}{l}\text { South } \\
\text { Africa }\end{array}$ & 2010 & $\begin{array}{l}\text { (Baloyi et } \\
\text { al., 2011) }\end{array}$ \\
\hline 2 & $\begin{array}{l}\text { Causes and effects } \\
\text { of project delays }\end{array}$ & $\begin{array}{c}\text { Strikes, } \\
\text { Rework, } \\
\text { Shortage of materials in the market (16) }\end{array}$ & $\begin{array}{l}\text { South } \\
\text { Africa }\end{array}$ & 2017 & $\begin{array}{l}\text { (Oshungade } \\
\text { et al., 2017) }\end{array}$ \\
\hline 3 & $\begin{array}{l}\text { Factors Causing } \\
\text { Delays }\end{array}$ & $\begin{array}{c}\text { Slow decision making, } \\
\text { Inadequate planning and scheduling, } \\
\text { Rain (122) }\end{array}$ & Kenya & 2015 & $\begin{array}{l}\text { (Seboru, } \\
2015)\end{array}$ \\
\hline 4 & $\begin{array}{l}\text { Schedule Delay } \\
\text { Factors }\end{array}$ & $\begin{array}{c}\text { Financial capability of the contractor, and } \\
\text { owner, Equipment availability, Slow } \\
\text { payments and (27) }\end{array}$ & $\begin{array}{l}\text { Burkina } \\
\text { Faso }\end{array}$ & 2016 & $\begin{array}{l}\text { (Bagaya, } \\
2016)\end{array}$ \\
\hline 5 & $\begin{array}{l}\text { Factors Affecting } \\
\text { Delays }\end{array}$ & $\begin{array}{c}\text { Delay in progress payment, } \\
\text { Difficulties in financing the project, } \\
\text { Change orders (46) }\end{array}$ & Zimbabwe & 2017 & $\begin{array}{l}\text { (Nyoni et } \\
\text { al., 2017) }\end{array}$ \\
\hline 6 & $\begin{array}{l}\text { Causes \& effects } \\
\text { of delay }\end{array}$ & $\begin{array}{c}\text { Poor financial control on-site, } \\
\text { Ineffective schedule and } \\
\text { Ineffective site management (37) }\end{array}$ & Zimbabwe & 2018 & $\begin{array}{l}\text { (Nyoni, } \\
2018)\end{array}$ \\
\hline 7 & $\begin{array}{l}\text { Causes and } \\
\text { Effects of Delay }\end{array}$ & $\begin{array}{l}\text { Shortages of resources, } \\
\text { Design-related factors, } \\
\text { Delays in payment }(70) \\
\end{array}$ & Sudan & 2016 & $\begin{array}{c}\text { (Khair et al., } \\
\text { 2016) }\end{array}$ \\
\hline 8 & $\begin{array}{l}\text { The framework to } \\
\text { Reduce Delays }\end{array}$ & $\begin{array}{c}\text { Finance competence, } \\
\text { Shortages of resources, } \\
\text { Design-related factors (35) }\end{array}$ & Sudan & 2018 & $\begin{array}{c}\text { (Khair et al., } \\
\text { 2018) }\end{array}$ \\
\hline 9 & Analysis of delays & $\begin{array}{l}\text { Consultant-related, } \\
\text { Material-related (25) } \\
\end{array}$ & Tanzanian & 2017 & $\begin{array}{l}\text { (Sambasivan } \\
\text { et al., 2017) }\end{array}$ \\
\hline 10 & $\begin{array}{l}\text { Mitigation } \\
\text { Measures for } \\
\text { Delays }\end{array}$ & $\begin{array}{c}\text { Planning and scheduling, } \\
\text { Design change, } \\
\text { Communication }(35) \\
\end{array}$ & Tanzanian & 2019 & $\begin{array}{c}\text { (Jongo et al., } \\
2019)\end{array}$ \\
\hline 11 & $\begin{array}{l}\text { Factors Causing } \\
\text { Delay }\end{array}$ & $\begin{array}{l}\text { Delay in revising and approving the design, } \\
\text { Delays in sub- contractor's work, } \\
\text { Poor communication, }(52)\end{array}$ & Nigeria & 2016 & $\begin{array}{l}\text { (Agu N. \& } \\
\text { Ibe, B.O., } \\
\text { 2015) }\end{array}$ \\
\hline 12 & $\begin{array}{l}\text { Causes and } \\
\text { Effects of delays }\end{array}$ & $\begin{array}{l}\text { Insufficient resources, } \\
\text { inaccurate time estimate, } \\
\text { payment difficulties, }(57)\end{array}$ & Nigeria & 2016 & $\begin{array}{l}\text { (Obodoh, } \\
\text { 2016) }\end{array}$ \\
\hline 13 & $\begin{array}{l}\text { Causes of Delays } \\
\text { and Cost } \\
\text { Overruns }\end{array}$ & $\begin{array}{l}\text { changes to the scope of work, } \\
\text { delayed payments, } \\
\text { poor monitoring and control, (20) }\end{array}$ & Uganda & 2013 & $\begin{array}{l}\text { (H. } \\
\text { Alinaitwe, } \\
\text { 2013) }\end{array}$ \\
\hline 14 & Causes of Delays & $\begin{array}{l}\text { shortage of resources, } \\
\text { insufficient contractor cash-flow, } \\
\text { slow payment procedures }(72)\end{array}$ & Malawi & 2013 & $\begin{array}{l}\text { (Kamanga et } \\
\text { al., 2013) }\end{array}$ \\
\hline 15 & $\begin{array}{l}\text { Project Delays on } \\
\text { Cost Overrun }\end{array}$ & Poor monitoring and control (8) & Rwanda & 2016 & $\begin{array}{l}\text { (Amandin et } \\
\text { al., 2016) }\end{array}$ \\
\hline 16 & $\begin{array}{l}\text { Factors Causing } \\
\text { Delays }\end{array}$ & $\begin{array}{l}\text { Inadequate project management assistance } \\
\text { managerial factors }(15)\end{array}$ & Algeria & 2018 & $\begin{array}{l}\text { (Roumeissa } \\
\text { et al., 2018) }\end{array}$ \\
\hline 17 & $\begin{array}{l}\text { Ranking of delay } \\
\text { factors }\end{array}$ & $\begin{array}{c}\text { Lack of consultant experience, } \\
\text { Delay approving, } \\
\text { Inaccurate site investigation, (99) }\end{array}$ & Egypt & 2013 & (Aziz, 2013) \\
\hline 18 & Causes of Delays & $\begin{array}{c}\text { Financing a shortage of contractor, } \\
\text { delays in payments, } \\
\text { design changes }(38)\end{array}$ & Egypt & 2008 & $\begin{array}{l}\text { (Mobarak, } \\
\text { 2008) }\end{array}$ \\
\hline 19 & $\begin{array}{l}\text { Delays in construc } \\
\text { tion }\end{array}$ & $\begin{array}{l}\text { Financial related, } \\
\text { scheduling and controlling related (32) }\end{array}$ & Ghana & 2010 & $\begin{array}{c}\text { (Fugar et al., } \\
\text { 2011) }\end{array}$ \\
\hline
\end{tabular}




\begin{tabular}{|c|c|c|c|c|c|}
\hline 20 & $\begin{array}{l}\text { Analyzing } \\
\text { construction delay } \\
\text { factors }\end{array}$ & $\begin{array}{l}\text { low skills of manpower, } \\
\text { changes in the scope of the project, } \\
\text { slowness in giving instruction, (18) }\end{array}$ & Libya & 2011 & $\begin{array}{l}\text { (Shebob et } \\
\text { al., 2011) }\end{array}$ \\
\hline 21 & $\begin{array}{l}\text { Causes of } \\
\text { Construction } \\
\text { Delay }\end{array}$ & $\begin{array}{l}\text { Difficulties in the financing, } \\
\text { Escalation of the materials price, } \\
\text { Infective project planning, scheduling, } \\
\text { resource management }(88)\end{array}$ & Ethiopia & 2016 & $\begin{array}{l}\text { (Hareru et } \\
\text { al., 2016) }\end{array}$ \\
\hline 22 & $\begin{array}{l}\text { Causes and } \\
\text { Effects of Delay }\end{array}$ & $\begin{array}{c}\text { Economic condition, } \\
\text { fluctuation in the price of material, } \\
\text { slow decision making, }(59)\end{array}$ & Ethiopia & 2020 & $\begin{array}{l}\text { (Serani et } \\
\text { al., 2020) }\end{array}$ \\
\hline 23 & $\begin{array}{l}\text { Study of schedule } \\
\text { delay }\end{array}$ & $\begin{array}{l}\text { Delay of the progress payment, } \\
\text { unrealistic contract duration, } \\
\text { rework due to the construction errors, (49) }\end{array}$ & Morocco & 2018 & $\begin{array}{l}\text { (Bajjou et } \\
\text { al., 2018) }\end{array}$ \\
\hline 24 & $\begin{array}{l}\text { evaluation of } \\
\text { delay factors }\end{array}$ & $\begin{array}{l}\text { Financial difficulties by the owner, } \\
\text { Changes in drawings of the architect, } \\
\text { Inadequate planning and scheduling of } \\
\text { contractor, (41) }\end{array}$ & Benin & 2013 & $\begin{array}{l}\text { (A. RKTM, } \\
\text { X. Feng, } \\
\text { 2013) }\end{array}$ \\
\hline
\end{tabular}

\subsection{Delays of construction projects}

Construction industry in the Africa today has undergone many innovations, and that is truly the locomotive of the national economy. The more resources, engineering, labor, materials, equipment, capital, and market exchange are provided from within the national economy, the higher the factor of the extent of self-reliance. The increasing complexity of infrastructure projects and the environment within which they are constructed place greater demand on construction managers to deliver projects on time, within the planned budget and with high quality.

The successful execution of construction projects and keeping them within estimated cost and prescribed schedules depend on a methodology that requires sound engineering judgment. To the dislike of owners, contractors and consultants, however, many projects experience extensive delays and thereby exceed initial time estimates. This problem is more evident in the traditional or adversarial type of contracts in which the contract is awarded to the lowest bidder- the awarding strategy of the majority of public projects in the African countries. Therefore, improving construction efficiency by means of cost-effectiveness and timeliness would certainly contribute to cost savings for the continent as a whole.

Construction projects are graded very successful if the work is completed within budget and to the deadlines agreed in the specification. However, the sad truth is that not all projects are guilty of being successful. Many projects experience failure due to the uncertainties associated with construction projects which include weather, materials, equipment, money and profitability, disagreements between clients, contractors and sub-contractors, statutory regulations, economic and political issues and functionality and purpose. To prevent these failures from constantly occurring, the types of failures need to be addressed so future construction projects do not fall into the same category of 'unsuccessful Civil Engineering construction projects'. It is clear that some of these failures occur regardless of careful planning due to uncontrollable conditions such as climate change, recession, delayed deliveries etc. Therefore, addressing the controllable issues, contractors can incorporate these problems into their specification. By understanding the issues from previous unsuccessful construction projects and correlating the failures, it will be easy to identify the common errors and try to eliminate them from future projects.

In construction projects a late completion is commonly referred to as the time between the actual deadlines agreed, to the time the project is completed. This is commonly called a delay in construction and tends to have a major effect on the client, end user, contractor and shareholders. If delays occur in construction projects, the contractor will be subjected to, Additional/Extension time of completion, immediate termination of contract, reduced profit or a mixture of the above. This is not always the case, as some delays are not the contractor's fault. The other parties involved in the construction stage are, clients, consultants and external influences e.g. suppliers, machinery, mother nature etc. Any delay will create problems between all/some of the parties involved.

\subsection{Delays of construction in developing countries}

The construction delay is a common problem in this part of the developing country. The critical factors for delay in this developing country are related to managerial and financial issues. For example, studies show that changes in initial designs, bad weather and subcontractor, variation and claims major sources of delay in Oman (Alnuaimi et al., 2013). Managerial issues such as inadequate planning and scheduling, ineffective site management, poor communication among the parties, imperfect contract management, etc. are the most critical factors of construction delays in India (H. Doloi, A. Sawhney, K. Iyer, 2012). Pakistan and Sri Lankan encountering delays by financial issues together with the shortage of equipment and materials, and environmental calamities (El-Sayegh, 2016 ; M. Haseeb, Xinhai-Lu, A. Bibi, M-Dyiian, 2011). Managerial issues, financial difficulties, shortages of resources like 
labor, materials, and equipment, along with contractors' inexperience are identified as the most influential factors for project delay in Malaysia (B. Honig, 2009; M. Haseeb, Xinhai-Lu, A. Bibi, M-Dyiian, 2011). Managerial issues, financial difficulties, shortages of resources like labor, materials, and equipment, along with contractors' inexperience, delay in design and change orders during construction are identified as critical influential factors for construction project delay in Indonesian, Thailand, Afghanistan, and Vietnam (I. A. Rahman, A. Memon, 2013; W. Alaghbari, M. R. a. Kadir, 2017)(L. Le-Hoai, Y. D. Lee, 2013; N. Long, S. Ogunlana, T. Quang, 2008; Niazai, 2012). The some to that, poor site management and lowest bidder selection are the most causes of delay in Bangladesh (M. S. Islam, B. Trigunarsyah, M. Hassanain, 2015). On the other hand, Construction projects in Kuwait, Iran, Lebanon have been suffering by schedule delay because of poor project management, change order in design, financial problem, environmental factors and lack of construction experience of the owner (A. Tarhini, M. Fakih, M. Arzoky, 2016; Ismail, 2012; P. a. Koushki, K. Al-Rashid, 2009). Shortage of materials and skilled labor, financial difficulties, change order, and slow decision making by owner and design difficulties are some critical issues for construction delay in Qatar, Palestine (Gaza Strip), Saudi Arabia and UAE (A. Enshassi, J. Alnajjar, 2009; Atibu Seboru, 2015; El-Sayegh, 2016; Mahamid, 2013; Younes, 2015).

\subsection{Delay in the African construction industry}

The construction industry in Africa has been experiencing a delay in project delivery due to very common causes, such as contractor's cash problem, and delay in progress payment by the owner, poor site management, and change order by owner. For other delay factors, there is no identical trend among the African countries. For example, South Africa construction projects are suffering by design-related factors, late decision-making, shortages of resources, strikes of labor, rework and

shortage of materials in the market (Baloyi et al., 2011; Oshungade et al., 2017). Similar problems have been identified for construction delay in Sudan (Khair et al., 2016, 2018). Delay in revising and approving the design, delays in subcontractors' work, poor communication, and change orders are major causes of delay in the Nigerian construction industry (Agu N. \& Ibe, B.O., 2015; Obodoh, 2016). Beyond these, insufficient resources, inaccurate time estimate, payment difficulties, poor site management, incompetent project team, improper project planning, and scheduling and contractors' financial difficulties are significant delay factors for the Nigerian construction industry. When we saw Egypt, lack of consultant experience, delay approving, inaccurate site investigation, inadequate project management assistance, financing shortage of contractors, delays in payments, and design changes were found the critical causes of construction delays (Aziz, 2013; Mobarak, 2008). Construction projects in Ghana are getting delay due to delays in financial shortages, scheduling, and controlling problems (Fugar et al., 2011). Delay in progress payment, difficulties in financing the project, change orders are the causes of delay in Zimbabwe construction projects (Nyoni et al., 2017). Besides, they have been experiencing delays because of poor financial control on-site, ineffective schedule, and ineffective site management (Nyoni, 2018). Financial capability of the contractor and owner, equipment availability, slow payments, and poor subcontractor performance are frequent and important factors of delay in Burkina Faso and Benin (A. RKTM, X. Feng, 2013; Bagaya, 2016). The construction industry in Uganda is facing problems due to changes to the scope of work, delayed payments, poor monitoring and control, and political insecurity and instability (H. Alinaitwe, 2013). In the case of Tanzania and Morocco, planning and scheduling, design change, communication, consultant, and material-related are the basic problems for construction delays (Bajjou et al., 2018; Jongo et al., 2019; Sambasivan et al., 2017). Difficulties in the financing, escalation of the materials price, infective project planning, scheduling or resource management, economic condition, and slow decision making the significant causes of delay in the Ethiopian construction industry (Hareru et al., 2016; Serani et al., 2020). Slow decision making, bureaucracy in client, inadequate planning and scheduling, rain, shortage of resources, insufficient contractor cash-flow, slow payment procedures, poor monitoring and control, managerial factors, low skills of manpower, changes in the scope of the project, slowness in giving instruction and delay in delivering site are the major sources of construction delay in Kenya, Malawi, Rwanda, Algeria and Libya (Amandin et al., 2016; Kamanga et al., 2013; Roumeissa et al., 2018; Seboru, 2015; Shebob et al., 2011). 
Table 2: African construction delays frequency and ranking

\begin{tabular}{|c|c|c|c|}
\hline \multirow{2}{*}{$\begin{array}{l}\text { Cause of } \\
\text { Delay } \\
\text { Groups }\end{array}$} & \multirow[t]{2}{*}{ Causes of delays from works of literature (65) } & \multicolumn{2}{|c|}{$\begin{array}{l}\text { Frequency and ranking of } \\
\text { construction delays }\end{array}$} \\
\hline & & $\begin{array}{l}\text { Frequency (out } \\
\text { of } 25 \text { studies) }\end{array}$ & Ranks \\
\hline \multirow{7}{*}{ Client } & Change/ Variations order & 17 & 1 \\
\hline & Late approval for payments & 16 & 2 \\
\hline & Slowness in decision making & 15 & 3 \\
\hline & Delay in site handover & 11 & 4 \\
\hline & Suspension of work & 10 & 5 \\
\hline & Lack of incentive for contractors to finish ahead of schedule & 9 & 6 \\
\hline & Difficulties in financing project & 8 & 7 \\
\hline \multirow{12}{*}{ Contractors } & Infective project planning, scheduling & 22 & 1 \\
\hline & Poor site management & 20 & 2 \\
\hline & Rework & 18 & 3 \\
\hline & Inadequate contractor's experience & 17 & 4 \\
\hline & Cash flow problems & 15 & 5 \\
\hline & Inappropriate construction method & 13 & 6 \\
\hline & Frequent change of subcontractors & 12 & 7 \\
\hline & Delay in site mobilization & 12 & 7 \\
\hline & Late delivery of material & 9 & 9 \\
\hline & Obsolete technology & 8 & 10 \\
\hline & Supplying poor quality material & 7 & 11 \\
\hline & Poor health and safety & 7 & 11 \\
\hline \multirow{6}{*}{ Consultant } & Delay in approving the major change & 19 & 1 \\
\hline & Poor site supervision & 18 & 2 \\
\hline & Late in revising and approving the design, tests, & 15 & 3 \\
\hline & Preparing Incomplete/ undetailed BoQ & 14 & 4 \\
\hline & Inadequate experience of the consultant & 12 & 5 \\
\hline & Late issue of instruction & 11 & 6 \\
\hline \multirow{7}{*}{$\begin{array}{l}\text { Design- } \\
\text { team }\end{array}$} & $\begin{array}{l}\text { Insufficient data collection and survey before design/site } \\
\text { investigation }\end{array}$ & 15 & 1 \\
\hline & Mistakes \& discrepancies in the design document & 11 & 2 \\
\hline & Inadequate design team experience & 9 & 3 \\
\hline & Delays in producing design documents & 9 & 3 \\
\hline & Non-use of advanced modern engineering design software & 9 & 3 \\
\hline & The complexity of project design & 8 & 6 \\
\hline & Misunderstanding of owner's requirements & 7 & 7 \\
\hline \multirow{3}{*}{ Financing } & Escalation of materials price & 7 & 1 \\
\hline & Fluctuation of price & 7 & 1 \\
\hline & Global financial crisis & 6 & 3 \\
\hline \multirow{6}{*}{$\begin{array}{l}\text { Manpower } \\
\text { and } \\
\text { Equipment }\end{array}$} & Unavailability of equipment & 14 & 1 \\
\hline & Low productivity of labor & 13 & 2 \\
\hline & Shortage of skilled labor & 13 & 2 \\
\hline & Shortage of recent technology equipment & 12 & 4 \\
\hline & Absenteeism and strikes & 10 & 5 \\
\hline & Unqualified/inadequate experienced labor & 9 & 6 \\
\hline
\end{tabular}




\begin{tabular}{|c|c|c|c|}
\hline \multirow{2}{*}{$\begin{array}{l}\text { Cause of } \\
\text { Delay } \\
\text { Groups }\end{array}$} & \multirow[t]{2}{*}{ Causes of delays from works of literature (65) } & \multicolumn{2}{|c|}{$\begin{array}{l}\text { Frequency and ranking of } \\
\text { construction delays }\end{array}$} \\
\hline & & $\begin{array}{l}\text { Frequency (out } \\
\text { of } 25 \text { studies) }\end{array}$ & Ranks \\
\hline \multirow{5}{*}{ Project } & Poor communication between the parties & 16 & 1 \\
\hline & Inadequate definition of substantial completion & 10 & 2 \\
\hline & The conflict between joint - Ownership of the project & 9 & 3 \\
\hline & Changes in the project scope & 9 & 3 \\
\hline & Owner interference & 8 & 3 \\
\hline \multirow{7}{*}{ Materials } & Shortage of materials in the market & 15 & 1 \\
\hline & Delay in material delivery & 11 & 2 \\
\hline & Poor quality of construction materials & 11 & 2 \\
\hline & $\begin{array}{c}\text { Change in materials type and specifications during } \\
\text { construction }\end{array}$ & 10 & 4 \\
\hline & Delay in manufacturing materials & 9 & 5 \\
\hline & Damage of delivered materials/Poor material management & 9 & 5 \\
\hline & Unreliable suppliers & 7 & 7 \\
\hline \multirow{5}{*}{$\begin{array}{l}\text { Contract } \\
\text { and } \\
\text { Contractual } \\
\text { relationship }\end{array}$} & Type of construction contract and bidding and award & 10 & 1 \\
\hline & Major legal disputes and negotiations & 10 & 1 \\
\hline & Mistakes and discrepancies in contract documents & 8 & 3 \\
\hline & Unrealistic contract duration imposes & 8 & 3 \\
\hline & Ineffective delay penalties & 6 & 5 \\
\hline \multirow{7}{*}{ External } & Unfavorable weather conditions & 14 & 1 \\
\hline & Delay in providing services from utilities & 10 & 2 \\
\hline & Changes in government regulations and laws & 10 & 2 \\
\hline & Accidents during construction & 9 & 4 \\
\hline & Delay in obtaining permits from the municipality & 9 & 4 \\
\hline & Conflict, war, and public enemy, Natural disaster & 8 & 6 \\
\hline & Inflation & 6 & 7 \\
\hline
\end{tabular}

\subsection{Critical factors of construction delay in Africa}

It is noticed that contractor, consultant, and client-related factors are found as the most frequent causes of delay. Table 3 shows a comparative list of the most important causes of delays encountered in African countries. For example, infective project planning and scheduling, delay in approving the major change, and change/variations order are having been found in 17 countries. Also, insufficient data collection and survey before design/site investigation and Poor communication between the parties are acknowledged as very high frequent causes, which have been found in 16 countries in the continent. Beyond these, unavailability of equipment, shortage of materials in the market, and unfavorable weather conditions are also some important and frequently encountered delay factors in some parts of Africa. 
Table 3: Critical causes of delay in Africa

\begin{tabular}{|c|c|c|c|c|c|c|c|c|c|c|}
\hline \multirow[t]{2}{*}{ Countries } & \multicolumn{10}{|c|}{ Frequency of the critical causes of delay $(\sqrt{ })$} \\
\hline & $\mathrm{CVO}$ & IPPS & DAMC & SI & FP & UE & PCP & SMM & TCCBA & UWC \\
\hline Kenya & $\sqrt{ }$ & $\sqrt{ }$ & $\sqrt{ }$ & $\sqrt{ }$ & $\sqrt{ }$ & $\sqrt{ }$ & $\sqrt{ }$ & $\sqrt{ }$ & $\sqrt{ }$ & $\sqrt{ }$ \\
\hline Burkina Faso & $\sqrt{ }$ & $\sqrt{ }$ & $\sqrt{ }$ & $\sqrt{ }$ & & $\sqrt{ }$ & $\sqrt{ }$ & $\sqrt{ }$ & & \\
\hline Zimbabwe & $\sqrt{ }$ & $\sqrt{ }$ & $\sqrt{ }$ & $\sqrt{ }$ & $\sqrt{ }$ & $\sqrt{ }$ & $\sqrt{ }$ & $\sqrt{ }$ & $\sqrt{ }$ & $\sqrt{ }$ \\
\hline Sudan & $\sqrt{ }$ & $\sqrt{ }$ & $\sqrt{ }$ & $\sqrt{ }$ & & $\sqrt{ }$ & $\sqrt{ }$ & $\sqrt{ }$ & & $\sqrt{ }$ \\
\hline Tanzanian & $\sqrt{ }$ & $\sqrt{ }$ & $\sqrt{ }$ & $\sqrt{ }$ & & $\sqrt{ }$ & $\sqrt{ }$ & $\sqrt{ }$ & $\sqrt{ }$ & $\sqrt{ }$ \\
\hline Nigeria & $\sqrt{ }$ & $\sqrt{ }$ & $\sqrt{ }$ & $\sqrt{ }$ & $\sqrt{ }$ & $\sqrt{ }$ & $\sqrt{ }$ & $\sqrt{ }$ & & $\sqrt{ }$ \\
\hline Uganda & $\sqrt{ }$ & $\sqrt{ }$ & $\sqrt{ }$ & $\sqrt{ }$ & & $\sqrt{ }$ & $\sqrt{ }$ & $\sqrt{ }$ & & $\sqrt{ }$ \\
\hline Malawi & $\sqrt{ }$ & $\sqrt{ }$ & $\sqrt{ }$ & $\sqrt{ }$ & & $\sqrt{ }$ & $\sqrt{ }$ & $\sqrt{ }$ & $\sqrt{ }$ & $\sqrt{ }$ \\
\hline Rwanda & & $\sqrt{ }$ & $\sqrt{ }$ & $\sqrt{ }$ & & $\sqrt{ }$ & $\sqrt{ }$ & & $\sqrt{ }$ & \\
\hline Algeria & $\sqrt{ }$ & $\sqrt{ }$ & $\sqrt{ }$ & $\sqrt{ }$ & & $\sqrt{ }$ & $\sqrt{ }$ & $\sqrt{ }$ & & $\sqrt{ }$ \\
\hline Egypt & $\sqrt{ }$ & $\sqrt{ }$ & $\sqrt{ }$ & $\sqrt{ }$ & $\sqrt{ }$ & & $\sqrt{ }$ & $\sqrt{ }$ & $\sqrt{ }$ & $\sqrt{ }$ \\
\hline Ghana & $\sqrt{ }$ & $\sqrt{ }$ & $\sqrt{ }$ & $\sqrt{ }$ & & $\sqrt{ }$ & $\sqrt{ }$ & & & $\sqrt{ }$ \\
\hline Libya & $\sqrt{ }$ & $\sqrt{ }$ & $\sqrt{ }$ & $\sqrt{ }$ & $\sqrt{ }$ & $\sqrt{ }$ & $\sqrt{ }$ & $\sqrt{ }$ & & $\sqrt{ }$ \\
\hline Ethiopia & $\sqrt{ }$ & $\sqrt{ }$ & $\sqrt{ }$ & $\sqrt{ }$ & & $\sqrt{ }$ & $\sqrt{ }$ & $\sqrt{ }$ & $\sqrt{ }$ & $\sqrt{ }$ \\
\hline South Africa & $\sqrt{ }$ & $\sqrt{ }$ & $\sqrt{ }$ & & & & & $\sqrt{ }$ & $\sqrt{ }$ & \\
\hline Morocco & $\sqrt{ }$ & $\sqrt{ }$ & $\sqrt{ }$ & $\sqrt{ }$ & $\sqrt{ }$ & $\sqrt{ }$ & $\sqrt{ }$ & $\sqrt{ }$ & $\sqrt{ }$ & $\sqrt{ }$ \\
\hline Benin & $\sqrt{ }$ & $\sqrt{ }$ & $\sqrt{ }$ & $\sqrt{ }$ & $\sqrt{ }$ & $\sqrt{ }$ & $\sqrt{ }$ & $\sqrt{ }$ & $\sqrt{ }$ & $\sqrt{ }$ \\
\hline
\end{tabular}

$\mathrm{CVO}=$ Change/Variations order, IPPS = Infective project planning, scheduling, DAMC $=$ Delay in approving the major change, $\mathrm{SI}=$ Insufficient data collection and survey before design/site investigation, $\mathrm{FP}=\mathrm{Fluctuation}$ of price, $\mathrm{UE}=$ Unavailability of equipment, $\mathrm{PCP}=$ Poor communication between the parties, $\mathrm{SMM}=$ Shortage of materials in the market, TCCBA=Type of the construction contract and bidding and award, UWC=Unfavorable weather conditions.

\section{Causes and effects of African construction delays}

\subsection{Potential causes of African construction delays and their frequency and ranking}

Construction delay studies in different African countries show that the delay factors can be classified according to the cause of delays (Table 1). Some studies made separate groups for delay causes related to construction materials, equipment, and manpower (Agu N. \& Ibe, B.O., 2015; Kamanga et al., 2013; Obodoh, 2016). Some other researches considered them as resources related factors, or two groups like manpower and equipment, and material, or material and manpower, and equipment (Mahamid, 2013; N. Long, S. Ogunlana, T. Quang, 2008; Oshungade et al., 2017). Beyond these groups, financial, managerial, government rules and regulations, and external factors were recognized as the common groups in most of the studies (Table 1). However, few studies added some more groups like contract and contractual relationship, design team, and project-related factors(H. Alinaitwe, 2013; Nyoni, 2018; Shebob et al., 2011). Based on these findings, this study classified the delay causes under 10 major groups, for example, client, contractor, consultant, design team, financing, manpower and equipment, project, material, contract, and contractual relationship and external. Besides, from the existing literature, 65 causes of delay under the 10 groups are identified. All these critical delay causes are listed in Table 2 and discussed briefly in the following subsections considering their frequency and ranking.

\subsubsection{Change /variations orders}

when it rises from any of the stockholders of the project before the project implementation it may not have a significant impact on project completion time, but when it came during the project; implementationchanges/variations in the requirements by the client significantly influence contract especially in terms of completion of the project. Normally such change /variations orders result in extended contract durations. This factor ranked $1^{\text {st }}$ in the client group of delay within 15 African countries. Owners may demand some design changes during construction, but owners also should consider their adverse effects on critical activities.

\subsubsection{Infective project planning and scheduling}

it is for the reason that, first project planers are not given attention for extreme weather conditions (commonly ignored during planning stage) which leads to the inappropriate estimation of labor productivity and thus an improper estimate of activity time, the second issue is an unproductive use of equipment results from the untimely mobilization of equipment leading to the idling of resources, thirdly poor coordination and improper flow of information among parties of the project which occurs due to lack of planning in order of events. In addition to that, limitation in material procurement (by contractor) is a result of improper scheduling or lack of understanding of lead time of materials delivery. Effective planning and scheduling lead to well-executed projects.

\subsubsection{Delay in approving major changes}

This is the critical and the most factor related to consultants' duty that leads to delay of construction projects within 
15 countries in Africa. This is due to before a change in the scope of work can be approved various committees are being involved such as design committee, finance committee, etc. These committees take their time to examine the reason for the change in scope, as to if there is a need for the change in the scope. The cost implication is also considered, as to if there are sufficient funds for the execution of the change in the scope of work. All these processes take time thereby leading to delay in approving the change in the scope of works.

\subsubsection{Insufficient data collection and survey before design/site investigation}

The design teams are the sole agent of investigating the site, collecting the required data, and conducting feasibility study about the proposed project and then preparing design and specification in the initial and design phases of construction. But in Africa, it is one of the root causes of delay for changes and variation during construction phases.

\subsubsection{Fluctuation of price}

These causes have resulted from either local or national or continental or global market prices and it can affect owner and contractor financial capabilities. Contractor financial problems might have resulted from either bad financial management at the site project level or the contractor company level. This bad financial management mostly caused by unrealistic project prices or cost estimate deficiency from the contractor side. Using a low price strategy for the project delivery system may force the contractor to reduce his profit percentage to project awarding and after that, the contractor will find himself in financial problems and un-capability to finance the project.

\subsubsection{Unavailability of equipment}

The timely availability of equipment in the required volume and quality is essential for the accomplishment of projects at the specified time. The unavailability of equipment is one of the African construction problems and it has a direct relationship with the contractor's financial difficulties, transportation, importation problems, and bureaucratic of countries. In most African countries the high rate of inflation and an increased fee of main materials make it hard to obtain equipment at the required time. It's also difficult to replace or repair the machinery which results in wasted time in performing works.

\subsubsection{Poor communication between the parties}

It is one of the major causes of delays in the African construction industry. It's due to delays in obtaining requisite permissions from local authorities caused as a result of a lack of communication with local authorities. It may be because of delay in the application process for obtaining permission or not having a follow-up or misapprehension of applied permission by local authorities. Failure to obtain consent from local authorities may not only interrupt the work schedule but can also lead to legal complications which may further contribute to time overruns. Beyond this, there may be a gap in communication between consultant and contractors to get an explanation about the practical technical hitches being encountered on-site and thus the need for change.

\subsubsection{Shortage of materials in the market}

The results show that this is an important factor that affects delay in construction projects in 13 African countries in the materials related groups of delay. In some African countries construction projects are now nearly come to termination due to material shortages in the country's market. This has been made worse due to the current liquidity crisis that has made it difficult for contractors to procure materials in time and the right quantities. On the other hand, materials suppliers are reluctant to supply materials on credit because contractors will normally pay suppliers only when they are paid.

\subsubsection{Type of construction contract and bidding and award}

This factor ranked $1^{\text {st }}$ in the contract and contractual relationship related groups of delay, within the frequency of 10 countries. Traditionally, contractor selection has been based solely on the prices offered by the bidder's which is list bidder bidding system. However, in many countries; nowadays, when it comes to selecting a contractor, owners do not consider the technical capacity and experiences of contractors, project types, as the major selection criterion. This implies that contractor selection is no longer a straightforward procedure performed by merely sorting the bids based on the offered price but rather a complicated process where owners now also consider a combination of several factors such as price, the reputation of the bidders, history of previous projects done by contractors, major construction quality indicators, suggested construction methods among other things. This implies that owners may occasionally fail to select the best contractor as the final winner of the bid. As a result, delay in construction projects in Africa becomes inevitable.

\subsubsection{Unfavorable weather conditions}

As indicated in table 2, authors from 14 African countries agreed that within the external group of delay factors, an unfavorable weather condition was a major delay factor. Bad weather conditions are natural events that cannot be controlled by the parties. In Africa, the effect of severe weather on progress have significant and needs to be taken into account. This is due to that, during the rainy and hot and dry season construction work may be disrupted especially outdoor activities. This affects the productivity of construction labors as a result of the dullness of their senses, poor coordination, and discomfort from body heat. 


\subsection{Effects of delays in African construction}

Construction project is a mission, to be undertake to create a unique facility, product or service within the specified scope, quality, time and cost. In practice, however, many construction projects encounter cost overrun, delay on completion time or poor workmanship upon completion. Beside many other reasons for these problems, the time and money which is lost due to controversies arising from claims could be raised as one reason.

Since construction industry in the continent, in general, is comparatively less organized and needs the involvement of trained professionals as compared to other sectors, because of a large amount of money invested in the sector from the country's scarce economy, extended completion time of projects and extra costs due to claims should be avoided or reduced and also it requires in-depth investigation to improve the out puts of the industry.

There are various consequences of construction delays on project performance. The delay in construction projects has huge impacts on time and cost overrun. Time overrun, cost overrun, wastages and underutilization of manpower, reduced profits, arbitration, litigation, disputes between parties, reduced economic growth, frustration and dissatisfaction of clients, tying down of client capital due to non-completion and total abandonment of projects are found the major effects of delay on African construction industry (Khair et al., 2016; Nyoni, 2018). However, cost overrun is considered as the most significant effect which may suspend or even terminate the project before completion. According to Oshungade (2017) create stress on the contractors, cost overrun, time overrun, and poor quality of work the four most important effects common to all the participants. Due to project delay in the long term, prices of materials, equipment, and labor costs will be incurred. Besides, economic inflation, the extra amount of bank interest, and indirect cost like salaries of the staff, and rental price of project offices increase. All these effects incurred a good amount of cost and directly increase project cost (Bajjou et al., 2018; Hareru et al., 2016).

\subsection{Possible mitigation measures for delays in Africa}

It is a general fact that the delay is a common phenomenon all over the world as well as in Africa. Studies have been done to find the mechanisms to reduces delays in construction projects. Some studies such as Amandin (2016), Jongo (2019), Nyoni (2018) and Nyoni (2017) states the flaws in the design documents should be timely addressed before or during implementation phases to avoid mistakes and discrepancies in design documents, the clients should have a proper orientation with contractors, designers and consultant engineers to minimize the changes in the scope of the project and should conduct weekly meetings or monitoring visits, timely decision making. Beyond this Contractors should rely on suitable, adequate, well repaired as well as modern, technologically advanced equipment and software. The choice of a project manager with sufficient knowledge and experience relevant to project management and the use of appropriate tools and techniques for the project has a great role in the minimization of construction delays (Khair et al., 2018). Construction clients must ensure that funds are available before projects are started, the long and bureaucratic processes involved in honoring payments to contractors must be shortened and contract provisions which allow contractors to claim interest on delayed payments must be strictly enforced to serve as a deterrent to clients are the critical mitigation ways of delay (Fugar et al., 2011). There are no straightforward solutions to the challenges of schedule delays in a construction project, however, systematic steps that can be taken to minimize their causes for the specific factors causing schedule delays in construction projects are suggested includes parties should review the payment clauses in the contract, the owners are recommended to define a realistic duration, contractors are recommended to monitor the quality of construction activities continuously to avoid any mistakes that may lead to rework and adopting new approaches to planning, such as LPS (Bajjou et al., 2018).

Generally when client select consultants, design teams, contractors and suppliers to the given projects, qualification takes into consideration many criteria such as experience working in similar projects, recorded performance, government agencies evaluation, financial capability, availability of technical staff, matching technical staff with project requirements, change the project-awarding system from lowest price strategy to another strategy, adding a penalty clause for delaying payment in the contract documents are the basic requirement to reduce occurrences and impact of delays. Besides this all relevant stakeholders must be involved at the planning stage of the project, considering weather conditions, accurate cost estimation to ensure project financing for both owner and contractor, efficient communication, skilled employees for all parties, capacity building, and appropriate legislation are required to minimize delays.

\subsection{Conclusions}

Worldwide the problem of delay in the construction industry is very acute \&severe. And there is a need to study more to improve this critical situation. This is a common issue found generally in every type of project and location. African construction industries are also facing the problem of delay. And if the situation is not handled properly the continent could suffer a gross domestic product loss. This study was aimed to find out the potential causes of construction delays and their effects on project delivery in African countries. For this reason, a good number of 
studies in this area have been reviewed. The causes of delay are classified into 10 major groups and 65 frequent causes of delay are found under these groups as significant in Africa. Among these causes, the change/variations order, infective project planning, scheduling, delay in approving the major change, insufficient data collection and survey before design, fluctuation of price, unavailability of equipment, poor communication between the parties, shortage of materials in the market, type of construction contract and bidding and award and unfavorable weather conditions the top ten causes of delay frequently occurred in most of the African country. The delays have serious effects on project objectives such as schedule and cost overrun of the project. It also creates claim, dispute, litigation, and arbitration among project stakeholders, which sometimes abandoned the project. To reduce construction delay in Africa, the client should reduce change order and pay progress payment regularly and the contractor should ensure preparing actual project scheduling by allowing sufficient time and conduct tight site management throughout the project. Besides improving approval of the major change, ensuring proper site investigation, timely procurement of equipment, material, and labor with effective and efficient way, modifying and improving the regulations and laws of nations, better communication and coordination with parties to take the required decisions on time are suggested for reducing delay.

\section{References}

A. Enshassi, J. Al-najjar, and M. K. (2009). Delays and cost overruns in the construction projects in the Gaza Strip. J. Financ. Manag. Prop. Constr., 14(2), 126-151.

A. RKTM, X. Feng, J. Z. (2013). Importance and ranking evaluation of delay factors for development construction projects in Benin. KSCE J Civil Eng., 17(6), 1213-1222.

A. Tarhini, M. Fakih, M. Arzoky, and T. T. (2016). Designing Guidelines to Discover the Causes of Delays in Construction Projects: The Case of Lebanon. Int. Bus. Res., 8(6), 73-88.

Agu N. \& Ibe, B.O., N. (2015). Assessment of Factors Causing Delay in Building Construction Projects in Enugu, Nigeria. International Journal of Innovative Science, Engineering \& Technology, 3(6), 544-558.

Alagidede, P., \& Mensah, J. O. (2016). Construction, institutions, and economic growth in sub-Saharan Africa. July.

Alnuaimi, A. S., \& Mohsin, M. A. Al. (2013). Causes of Delay in Completion of Construction Projects in Oman. International Conference on Innovations in Engineering and Technology (ICIET'2013) Dec. 25-26, 2013 Bangkok (Thailand), 99231200.

Amandin, M. M., \& Kule, J. W. (2016). Project Delays on Cost Overrun Risks: A Study of Gasabo District Construction Projects Kigali, Rwanda. ABC Journal of Advanced Research, 5(1), 21-34. DOI: 10.18034/abcjar.v5i1.55

Atibu Seboru, M. (2015). An Investigation into Factors Causing Delays in Road Construction Projects in Kenya. American Journal of Civil Engineering, 3(3), 51. DOI: 10.11648/j.ajce.20150303.11

Aziz, R. F. (2013). Ranking of delay factors in construction projects after the Egyptian revolution. Alexandria Engineering Journal, 52(3), 387-406. DOI: 10.1016/j.aej.2013.03.002

B. Honig. (2009). Identifying the Important Causes of Delays in Building Construction Projects. The 9th East Asia-Pacific Conference on Structural Engineering and Construction.

Bagaya, O. (2016). An Analysis of Schedule Delay Factors in Public Construction Projects : The Case of Burkina Faso An Analysis of Schedule Delay Factors in Public Construction Projects: The Case of Burkina Faso. October. DOI: 10.13140/RG.2.2.11587.60963

Bajjou, M. S., \& Chafi, A. (2018). An empirical study of schedule delay in Moroccan construction projects. International Journal of Construction Management, September. DOI: 10.1080/15623599.2018.1484859

Baloyi, L., \& Bekker, M. (2011). Causes of construction cost and time overruns: The 2010 FIFA World Cup stadia in South Africa. Acta Structilia, 51-67.

Bank, A. D. (2018). African Economic Outlook. In Annual yearly review study. DOI: 10.1373/clinchem.2007.093781

Burke, C., \& Corkin, L. (2006). China's Interest and Activity in Africa's Construction and Infrastructure Sectors A research undertaking evaluating China's involvement in Africa's construction and infrastructure sector prepared for DFID China. Centre for Chinese Studies, November, 110. Retrieved from https://www.icafrica.org/fileadmin/documents/Knowledge/DFID/China's Interest and Activity in Africa's Infrastructure and Construction Sectors.pdf

Edinger, H. (2019). Capital Projects in a Digital age Africa Construction Trends Report 2019. 1-25.

El-Sayegh, A. F., and S. (2016). Significant factors causing a delay in the UAE construction industry. Constr. Manag. Econ, 24(11), 1167-1176.

For, D., Cement, G., \& Africa, I. (2020). Construction Industry In Africa Bounces Back. 1-8.

Fugar, F. D., \& Agyakwah-Baah, A. B. (2011). Delays in Building Construction Projects in Ghana. Construction Economics and Building, 10(1-2), 103-116. DOI: 10.5130/ajceb.v10i1-2.1592

H. Alinaitwe, R. A., and D. T. (2013). An investigation into the Causes of Delays and Cost Overruns in Uganda's 
Public Sector Construction Projects. Journal of Construction in Developing Countries, 18(2), 33-47.

H. Doloi, A. Sawhney, K. Iyer, and S. R. (2012). Analyzing factors affecting delays in Indian construction projects. Nt. J. Proj. Manag., 30(4), 479-489.

Hareru, W., Neeraj Jha, K., Koshe, W., \& Jha, K. N. (2016). Investigating Causes of Construction Delay in Ethiopian Construction Industries. Journal of Civil, Construction and Environmental Engineering, 1(1), 1829. DOI: $10.11648 / \mathrm{j}$.jccee.20160101.13

I. A. Rahman, A. Memon, and A. T. K. (2013). Significant Factors Causing Cost Overruns in Large Construction Projects in Malaysia. J. Appl. Sci., 13(2), 286-293.

Ismail, T. P., and A. (2012). Causes and Effects of Delay in Iranian Construction Projects. Int. J. Eng. Technol., $4(5), 598-601$.

Jongo, J. S., Tesha, D. N. G. A. K., Kasonga, R., Teyanga, J. J., \& Lyimo, K. S. (2019). Mitigation Measures in Dealing with Delays and Cost Overrun in Public Building Projects in Dar-Es-Salaam, Tanzania. 8(3), 81-96. DOI: $10.5923 /$ j.ijcem.20190803.01

Kamanga, M. J., \& Steyn, W. J. V. D. M. (2013). Causes of delay in road construction projects in Malawi. Journal of the South African Institution of Civil Engineering, 55(3), 79-85.

Khair, K., Farouk, H., Mohamed, Z., \& Mohammad, R. (2016). Causes and effects of delay factors in road construction projects in Sudan. International Journal of Applied Engineering Research, 11(18), 9526-9533.

Khair, K., Mohamed, Z., Mohammad, R., Farouk, H., \& Ahmed, M. E. (2018). A Management Framework to Reduce Delays in Road Construction Projects in Sudan. Arabian Journal for Science and Engineering, 43(4), 1925-1940. DOI: 10.1007/s13369-017-2806-6

L. Le-Hoai, Y. D. Lee, and J. Y. L. (2013). Delay and cost overruns in Vietnam large construction projects: A comparison with other selected countries. KSCE J. Civ. Eng, 12(6), 367-377.

Lopes, J. P. (2010). Construction and economic growth in developing countries of Africa: evidence from data of the last thirty years. CIB World Building Congress, January 2010.

M. Haseeb, Xinhai-Lu, A. Bibi, M-Dyiian, and R. W. (2011). Problems of Projects and Effects of Delays in the Construction Industry of Pakistan. Aust. J. Bus. Manag. Res., 1(5), 41-50.

M. S. Islam, B. Trigunarsyah, M. Hassanain, and S. A. (2015). Causes of delay in construction projects in Bangladesh. The 6th International Conference on Construction Engineering and Project Management (ICCEPM 2015).

Mahamid, I. (2013). Contributors to Schedule Delays in Public Construction Projects in Saudi Arabia: Owners' Perspective. J. Constr. Proj. Manag. Innov, 3(2), 608-619,.

Mobarak, 45. M. E. Abd El-Razek; H. A. Bassioni; and A. M. (2008). Causes of Delay in Building Construction,on Projects in Egypt. Journal of Construction Engineering and Management, 134(11). DOI: ISSN 07339364/2008/11-831-841/

N. Long, S. Ogunlana, T. Quang, and K. L. (2008). Large construction projects in developing countries: a case study from Vietnam. Int. J. Proj. Manag., 22, 553-561.

Niazai, K. G., and G. (2012). Causes of project delay in the construction industry in Afghanistan. EPPM 2012, 63-74.

Nyoni, T. (2018). An Empirical Assessment of Causes \& Effects of Delay in Residential Construction Projects in. $5(1), 34-46$.

Nyoni, T., \& G.Bonga, W. (2017). Towards factors affecting delays in construction projects : A case of Libya. Journal of Economics and Finance, 2(1), 12-28.

Obodoh, D. A. (2016). Causes and Effects of Construction Project Delays in the Nigerian Construction Industry. IJISET -International Journal of Innovative Science, Engineering \& Technology, 3(5), 65-84. Retrieved from www.ijiset.com

Ofori, G. (2000). Challenge of Construction Sector in Developing Country. 2nd International Conference on Construction in Developing Countries: Challenges Facing the Construction Industry in Developing Countries, 15-17, Nov, 1-13. DOI: 10.1.1.198.2916

Oshungade, O. O., \& Kruger, D. (2017). A Comparative Study of Causes and Effects of Project Delays and Disruptions in Construction Projects in the South African Construction Industry. Journal of Construction Engineering and Project Management, 7(1), 13-25. DOI: 10.6106/jcepm.2017.3.30.013

P. a. Koushki, K. Al-Rashid, and N. K. (2009). Delays and cost increases in the construction of private residential projects in Kuwait. Constr. Manag. Econ, 23(3), 285-294.

Roumeissa, S., Karima, M., \& Souad, S. B. (2018). Identification of Factors Causing Delays in Construction Projects in Algeria. European Journal of Engineering and Formal Sciences, 2(1), 6. DOI: 10.26417/ejef.v2i1.p6-11

Sambasivan, M., Deepak, T. J., Salim, A. N., \& Ponniah, V. (2017). Analysis of delays in Tanzanian construction industry Transaction cost economics (TCE) and structural equation modeling (SEM) approach. Engineering, Construction, and Architectural Management, 24(2), 308-325. DOI: 10.1108/ECAM-09-2015-0145 
Seboru, M. (2015). An Investigation into Factors Causing Delays in Road Construction Projects in Kenya. American Journal of Civil Engineering., 3(3), 51-63. DOI: 10.11648/j.ajce.20150303.11

Serani, N., Tadele, D., \& Bayeh, W. (2020). The Causes and Effects of Delay of Building Construction in Ethiopia, Southern Nation Nationalities of People Region in Gurage Zone (Case of Wolkite Town). Civil and Environmental Research, 12(1), 12-21. DOI: 10.7176/cer/12-1-02

Shebob, A., Dawood, N., \& Xu, Q. (2011). Analyzing construction delay factors: A case study of building construction projects in Libya ANALYSING CONSTRUCTION DELAY FACTORS: A CASE STUDY OF BUILDING CONSTRUCTION PROJECT IN LIBYA. September, 5-7.

UN.ECA. (2016). Enhancing domestic private sector development in Africa: A focus on renewable energy.

W. Alaghbari, M. R. a. Kadir, and A. S. (2017). The significant factors causing the delay in building construction projects in Malaysia. Eng. Constr. Archit. Manag, 4(2), 192-206.

Younes, A. M. J. and J. H. (2015). Principal Factors Contributing to Construction Delays in the State of Qatar. Int.J. Constr. Proj. Manag, 6(1), 41-62. 